\title{
Politiske meningsmålinger
}

\begin{abstract}
En gennemgang af de seks storste producenter af politiske meningsmálinger i Danmark viser stor variation i de anvendte metoder, hvad angár undersøgelsetype, udvalg, udspergning og svarprocent. Derimod er der ikke den samme variation i deres evne til at forudsige udfaldet af folketingsvalgene 198494. Ved de tre seneste valg i 1988, 1990 og 1994 lả Gallups seneste máling tættest pă valgresultatet, men for de tidligere málinger i valgkampen var der ikke de store forskelle mellem analyseinstitutterne.
\end{abstract}

Hvor gyldige er de private analyseinstitutters politiske meningsmålinger? Dette spørgsmål tages hyppigt op i international litteratur om politiske meningsmålinger (se for eksempel Jowell m.fl., 1993; Crespi, 1988; Holmberg og Petersson, 1980). I Danmark er spørgsmålet mest blevet belyst ved journalistisk avisomtale. En undtagelse er en artikel om Gallups politiske indeks for perioden 1957-1980, som påviste god overensstemmelse med valgresultaterne, specielt for de større partier (Larsen, 1987). Et andet dansk eksempel er en debatbog om direkte demokrati, der blandt andet omtaler de betydelige afvigelser $\mathrm{i}$ forbindelse med de forskellige prognoser for EU-folkeafstemningen i 1992 (Schmidt: 15-17). Sidstnæunte bog bringer også en del illustrative eksempler på effekten af forskellige spørgsmålsformuleringer i politiske meningsmålinger.

I denne artikel vil jeg koncentrere mig om målingen af de politiske partiers tilslutning $\mathrm{i}$ forbindelse med de seneste folketingsvalg. Det vil sige, at jeg ikke direkte vil behandle de politiske meningsmålingers gyldighed i forbindelse med andre typer valg (kommunevalg, EU-valg, folkeafstemninger) samt $\mathrm{i}$ forbindelse med målinger af politiske holdninger.

Jeg vil forsøge at give et svar på spørgsmålet om målingernes gyldighed ud fra to synsvinkler. Den ene er at se nærmere på de metoder, de enkelte institutter anvender, og vurdere, om de lever op til de krav, man i dag kan stille. Den anden synsvinkel er at se på, hvor troværdige resultaterne har været. Specielt vil jeg undersøge, $\mathrm{i}$ hvor høj grad målingerne har kunnet fungere som prognoser for de faktiske valgresultater.

Spørgsmålet om de politiske meningsmålingers tilforladelighed vil blive besvaret inden for bestemte begrænsninger. For det første vil jeg kun se på de seks største danske producenter af meningsmålinger, nemlig AIM/Nielsen, Gallup, GfK/Observa, Greens, Sonar og Vilstrup. ${ }^{1}$ Dette er dog ikke nogen særlig begrænsning, da disse seks institutter i dag stort set står for hele produktionen af seriøse politiske meningsmålinger.

For det andet vil vurderingen af metoderne bygge på institutternes egen fremstilling. Jeg vil således ikke forsøge at sætte spørgsmålstegn ved, hvorvidt hvert institut faktisk lever op til sine egne erklærede principper. 


\title{
Politiske meningsmålinger
}

\begin{abstract}
En gennemgang af de seks storste producenter af politiske meningsmálinger i Danmark viser stor variation i de anvendte metoder, hvad angár undersøgelsetype, udvalg, udspergning og svarprocent. Derimod er der ikke den samme variation i deres evne til at forudsige udfaldet af folketingsvalgene 198494. Ved de tre seneste valg i 1988, 1990 og 1994 lả Gallups seneste máling tættest pă valgresultatet, men for de tidligere málinger i valgkampen var der ikke de store forskelle mellem analyseinstitutterne.
\end{abstract}

Hvor gyldige er de private analyseinstitutters politiske meningsmålinger? Dette spørgsmål tages hyppigt op i international litteratur om politiske meningsmålinger (se for eksempel Jowell m.fl., 1993; Crespi, 1988; Holmberg og Petersson, 1980). I Danmark er spørgsmålet mest blevet belyst ved journalistisk avisomtale. En undtagelse er en artikel om Gallups politiske indeks for perioden 1957-1980, som påviste god overensstemmelse med valgresultaterne, specielt for de større partier (Larsen, 1987). Et andet dansk eksempel er en debatbog om direkte demokrati, der blandt andet omtaler de betydelige afvigelser $\mathrm{i}$ forbindelse med de forskellige prognoser for EU-folkeafstemningen i 1992 (Schmidt: 15-17). Sidstnæunte bog bringer også en del illustrative eksempler på effekten af forskellige spørgsmålsformuleringer i politiske meningsmålinger.

I denne artikel vil jeg koncentrere mig om målingen af de politiske partiers tilslutning $\mathrm{i}$ forbindelse med de seneste folketingsvalg. Det vil sige, at jeg ikke direkte vil behandle de politiske meningsmålingers gyldighed i forbindelse med andre typer valg (kommunevalg, EU-valg, folkeafstemninger) samt $\mathrm{i}$ forbindelse med målinger af politiske holdninger.

Jeg vil forsøge at give et svar på spørgsmålet om målingernes gyldighed ud fra to synsvinkler. Den ene er at se nærmere på de metoder, de enkelte institutter anvender, og vurdere, om de lever op til de krav, man i dag kan stille. Den anden synsvinkel er at se på, hvor troværdige resultaterne har været. Specielt vil jeg undersøge, $\mathrm{i}$ hvor høj grad målingerne har kunnet fungere som prognoser for de faktiske valgresultater.

Spørgsmålet om de politiske meningsmålingers tilforladelighed vil blive besvaret inden for bestemte begrænsninger. For det første vil jeg kun se på de seks største danske producenter af meningsmålinger, nemlig AIM/Nielsen, Gallup, GfK/Observa, Greens, Sonar og Vilstrup. ${ }^{1}$ Dette er dog ikke nogen særlig begrænsning, da disse seks institutter i dag stort set står for hele produktionen af seriøse politiske meningsmålinger.

For det andet vil vurderingen af metoderne bygge på institutternes egen fremstilling. Jeg vil således ikke forsøge at sætte spørgsmålstegn ved, hvorvidt hvert institut faktisk lever op til sine egne erklærede principper. 


\section{Baggrund}

Med henblik på politologiske analyseformål har jeg oprettet et edb-dataarkiv med samtlige meningsmålinger af partiernes nationale tilslutning siden 1974.² Disse oplysninger er blandt andet brugt til at vurdere overensstemmelsen mellem det enkelte instituts målinger op til hvert folketingsvalg og det faktiske valgresultat. Endvidere er de med gunstigt resultat blevet brugt til at forudsige udfaldet af kommunale valg i Danmark (Thomsen, 1993).

I forbindelse med folketingsvalget i september 1994 kontaktede jeg de seks analyseinstitutter for at få dem til at redegøre for deres metodiske principper. På grund af konkurrenceforholdet mellem institutterne havde jeg forventet en vis tilbageholdenhed med at afsløre egne metoder, men jeg blev faktisk glædeligt overrasket over deres venlige imødekommenhed. ${ }^{3}$ Formålet med min kontakt til institutterne var ikke at få en udtømmende beskrivelse af deres metoder, men at få en klar forestilling om væsentlige ligheder og forskelle mellem de forskellige metoder. Min personlige opfattelse er, at dette formål i alle tilfælde blev opfyldt. Kun når jeg kom ind på detaljerede procedurer, stødte jeg undertiden på "forretningshemmeligheder".

\section{Metoderne}

I den følgende tabel 1 har jeg søgt at give en oversigt over nogle væsentlige træk ved de forskellige institutters metoder, som de var udformet i 1994 snecielt med henblik på institutternes månedlige målinger.

En væsentlig forudsætning for at forstå arbejdsmetoderne er, at de først og fremmest har markedsanalyser som formål $\mathrm{og}$ indtjeningsgrundlag. Det anslås, at over 90 pct. af institutternes analyser er forbrugsundersøgelser for private eller offentlige firmaer og organisationer (Schmidt, 1992: 121). Eneste undtagelse er Greens Analyseinstitut, som ud over at lave politiske meningsmålinger for dagbladet Børsen kun laver konjunkturanalyser.

Institutternes kommercielle sigte betyder imidlertid ikke en stedmoderlig behandling af de politiske meningsmålinger - snarere tværtimod. Det er nemlig således, at meningsmålingerne giver offentlig omtale af instituttet og på godt og ondt demonstrerer kvaliteten af de analyser, de er i stand til at foretage. Ved meningsmålingerne kan man yderligere drage fordel af de erfaringer og de indarbejdede procedurer for løbende udvælgelse og interviewing, som instituttet har udviklet i forbindelse med markedsanalyserne.

Næsten alle institutterne har lang erfaring at trække på. Det fremgår således af tabel 1, at de fire institutter AIM, Gallup, GfK/Observa og Vilstrup har lavet meningsmålinger i mindst 20 år. Endvidere repræsenterer Sonar en lignende erfaring, da firmaet er stiftet og ledet af den tidligere ansvarlige for Observas meningsmålinger.

Firmaernes erfaring er ikke alene lang, men også intensiv. Fem institutter laver således - samtidig med de månedlige målinger af partiernes tilslutning andre former for meningsmålinger til offentliggørelse $i$ landsdækkende dagblade. AIM har ikke en fast månedlig offentliggørelse af meningsmålinger, men varetager ofte meningsmålinger for forskere og for forskellige medier. ${ }^{4}$ 
Tabel 1. Skematisk oversigt over de enkelte institutter og deres metoder i 1994*

\begin{tabular}{|c|c|c|c|c|c|c|}
\hline & $\begin{array}{l}\text { AIM } \\
\text { Nielsen }\end{array}$ & Gallup & $\begin{array}{l}\text { GfK } \\
\text { Observa }\end{array}$ & Greens & $\begin{array}{l}\text { Sensor/ } \\
\text { Sonar }\end{array}$ & $\begin{array}{l}\text { Vilstrup } \\
\text { Research }\end{array}$ \\
\hline $\begin{array}{l}\text { Markeds- } \\
\text { analyser }\end{array}$ & $\mathrm{Ja}$ & $\mathrm{Ja}$ & $\mathrm{Ja}$ & Nej & $\mathrm{Ja}$ & $\mathrm{Ja}$ \\
\hline $\begin{array}{l}\text { Meningsm. } \\
\text { siden }\end{array}$ & 1974 & 1945 & 1967 & 1989 & 1989 & 1971 \\
\hline $\begin{array}{l}\text { Offentlig- } \\
\text { gorelse }\end{array}$ & Varierende & $\begin{array}{l}\text { Berlingske } \\
\text { Tidende }\end{array}$ & B.T. & Børsen & $\begin{array}{l}\text { Jyllands- } \\
\text { Posten }\end{array}$ & Politiken \\
\hline Kontakt & Telefon & Telefon & Post & Telefon & Post & Telefon \\
\hline Stikprove & $\begin{array}{l}\text { Tilf.tlf. } \\
\text { numre }\end{array}$ & $\begin{array}{l}\text { Tilf.tlf. } \\
\text { numre }\end{array}$ & Panel & $\begin{array}{l}\text { Tilf.tlf. } \\
\text { numre }\end{array}$ & Panel & $\begin{array}{l}\text { System.tlf. } \\
\text { numre }\end{array}$ \\
\hline Udv.kriterium & $\begin{array}{l}\text { Forst fød- } \\
\text { selsdag }\end{array}$ & $\begin{array}{l}\text { Forst fød- } \\
\text { selsdag }\end{array}$ & Kvoter & $\begin{array}{l}\text { Tager } \\
\text { telefonen }\end{array}$ & $\begin{array}{l}\text { Tilfældig } \\
\text { udvælg./ } \\
\text { kvoter }\end{array}$ & $\begin{array}{l}\text { Til stede. } \\
\text { Yngste mand/ } \\
\text { kvinde }\end{array}$ \\
\hline Svar-pct. & knap 70 & godt 80 & $80-90$ & ca. 60 & $80-90$ & ca. 65 \\
\hline Gennemfort & ca. 1.050 & ca. 1.050 & ca. 1.150 & godt 1.000 & ca. 1.100 & godt 1.000 \\
\hline Sporgsmál & $\begin{array}{l}\text { Hvilket } \\
\text { parti? }\end{array}$ & $\begin{array}{l}\text { Hvad ville } \\
\text { De stemme? }\end{array}$ & $\begin{array}{l}\text { Hvilket } \\
\text { parti? }\end{array}$ & $\begin{array}{l}\text { Hvad ville } \\
\text { De stemme? }\end{array}$ & $\begin{array}{l}\text { Hvilket } \\
\text { parti? }\end{array}$ & $\begin{array}{l}\text { Mest sandsynl. } \\
\text { parti? }\end{array}$ \\
\hline Sondering & $\begin{array}{l}\text { Anvendes } \\
\text { ikke }\end{array}$ & $\begin{array}{l}\text { Hælder mod } \\
\text { særl.parti? }\end{array}$ & $\begin{array}{l}\text { Unødven- } \\
\text { digt }\end{array}$ & $\begin{array}{l}\text { Hvilken } \\
\text { blok? }\end{array}$ & $\begin{array}{l}\text { Unødven- } \\
\text { digt }\end{array}$ & $\begin{array}{l}\text { Hvilke pá } \\
\text { tale? }\end{array}$ \\
\hline $\begin{array}{l}\text { Demogr. } \\
\text { vejning }\end{array}$ & $\mathrm{Ja}$ & $\mathrm{Ja}$ & $\mathrm{Ja}$ & $\mathrm{Ja}$ & $\mathrm{Ja}$ & $\mathrm{Ja}$ \\
\hline $\begin{array}{l}\text { Politisk } \\
\text { "vejning" }\end{array}$ & $\mathrm{Nej}$ & $\mathrm{Ja}$ & $\mathrm{Ja}$ & $\mathrm{Ja}$ & $\mathrm{Ja}$ & $\mathrm{Ja}$ \\
\hline
\end{tabular}

* Særlige forhold i forbindelse med valgkampen i 1994 er narmere omtalt i teksten.

\section{To typer undersøgelser}

Fra en metodisk synsvinkel er der væsentlig forskel mellem på den ene side GfK/Observas og Sonars politiske meningsmålinger og på den anden side meningsmålingerne foretaget af de fire øvrige institutter. De to første institutter interviewer nemlig hver for sig et fast "panel" af svarpersoner fra gang til gang med et postspørgeskema, mens de øvrige ved hver måling udtager en ny stikprøve, som interviewes telefonisk. ${ }^{5}$

Begge fremgangsmåder har såvel fordele som ulemper. Den største fordel ved panel-metoden er formentlig, at man fra måling til måling undgår udsving, som alene skyldes den statistiske usikkerhed mellem uafhængige stikprøver. Ser man bort fra de mindre udskiftninger, som løbende foretages i GfKs og Sonars paneler, betyder for eksempel en fremgang i socialdemokratisk tilslutning, at nogle faste svarpersoner faktisk angiver at have skiftet partivalg mellem to målinger. Derimod kan en lignende fremgang for Socialdemokratiet hos 
et af de øvrige institutter alene skyldes, at man tilfældigvis kommer til at udvælge flere socialdemokratiske vælgere til den nye stikprøve end til den gamle."

Som kritik mod panel-metoden kan det anføres, at de faste svarpersoner påvirkes af at være i panelet ved for eksempel af udvikle større interesse for politik og dermed ikke længere er repræsentative for vælgerbefolkningen. Endvidere er der også en tendens til, at de mindst interesserede oftere falder fra. Det siger sig selv, at GfK og Sonar prøver at kompensere for disse skævheder blandt andet i forbindelse med den løbende supplering med nye panel-deltagere; men det er nok vanskeligt at undgå, at panelet får lidt karakter af et "elitevælgerkorps". Svarpersonerne søges i begge paneler fastholdt ved deltagelse i mindre præmiekonkurrencer og lignende. GfK oplyser, at personerne søges fastholdt $\mathrm{i}$ tre-fire år, mens Sonar tilstræber en periode på maksimalt to år.

AIM, Gallup, Greens og Vilstrup anvender som nævnt telefoninterviews til de løbende politiske meningsmålinger. Alle firmaerne drager $i$ den forbindelse nytte af den moderne CATI-teknologi, herunder computerstyret opkald og edb-registrering af svarene. ${ }^{7}$ Det er et oplagt problem, at personer uden telefon ikke kan interviewes; men denne gruppe udgjorde allerede i 1984 kun syv pct. af den voksne befolkning (Cristoffersen, 1984). Et andet problem er, om folk giver gyldige svar, når de ikke sidder ansigt til ansigt med intervieweren; men en nærmere undersøgelse viser, at folk snarere er mere villige til at svare ærligt på nærgående spørgsmål i telefonen end direkte over for intervieweren (Körmendi m.fl., 1986).

Telefoninterviews er særlig anvendelige, når man i løbet af meget kort tid for eksempel samme dag som et valg udskrives eller dagen for valget - skal foretage en meningsmåling. Postforespørgsler og personlige interviews kræver længere tid til forberedelse og afvikling.

\section{Stikprøven}

Formålet med en stikprøve er naturligvis at få et repræsentativt billede af den bagvedliggende population (vælgerbefolkningen) med et mindre antal svarpersoner, typisk ca. 1.000. I stikprøven behøver der ikke at være de samme andele fra de forskellige befolkningsgrupper (strata) som i populationen, men det er vigtigt, at man for enhver person i populationen på forhånd kan angive sandsynligheden for, at vedkommende kommer med i stikproven. Det er i dag anerkendt, at den bedste måde at opnå en repræsentativ stikprøve er ved at anvende en eller anden form for tilfældig udvælgelse inden for hvert stratum. Vælger man specielt at lade hele befolkningen være et enkelt stratum, hvor alle har samme chance for at komme med i stikprøven, siger man, at stikprøven er udtaget simpel tilfældigt. Det er en udbredt misforståelse, at en simpel tilfældig stikprøve er den bedste form for udvælgelse. Faktisk får man med den samme stikprøvestørrelse i reglen større sikkerhed, dvs. mindre fejlmargen, med stratificeret tilfældig udvælgelse (se for eksempel Mortensen, 1994: 217-241).

Det gæider for aiie institutter bortset fra GזK, at stikprøven stort set udiages efter det princip, at man først udvælger nogle private husstande med telefon og dernæst udvælger en bestemt person inden for hver husstand. Specielt hvad 
angår det første trin i denne udvælgelse, hvor husstanden skal udvælges, ser det ud til, at de fem institutter anvender teknikker, som sikrer en passende tilfældig udvælgelse. Derimod er der flere problemer forbundet med det andet trin, hvor en person skal udvælges inden for husstanden.

I det første trin anvender AIM og Sonar simpel tilfældig udvælgelse af telefonnumre i hele landet. Forskellen er dog, at mens AIM lader computeren generere et tilfældigt telefonnummer for et telefonopkald, făr Sonar konstrueret en stor pulje af simpel tilfældigt udvalgte telefonnumre, som over en periode på to år bruges til løbende supplering af panelet. Hos Gallup og Greens er der også tale om tilfældig udvælgelse af telefonnumre, men inden for geografiske strata. Telefonnumre fravælges, hvis det ved opkaldet viser sig, at der ikke er tale om en privat husstand.

Vilstrup anvender i første trin en teknik, som umiddelbart ikke ser ud til at være tilfældig udvælgelse, men i princippet alligevel fungerer sådan. Vilstrup anvender nemlig systematisk fremtælling i regionale telefonnavnebøger, hvilket vil sige, at man gentagne gange tæller et fast antal telefonnumre frem i telefonbogen, og hver gang udvælger det telefonnummer, man er kommet frem til (firma- og institutionstelefoner springes over). Da der ikke er nogen periodisk systematik i telefonbogen, kommer denne metode i praksis til at fungere som et tilfældigt udtræk, hvor alle geografiske områder er lige stærkt repræsenteret (proportional statificering). Et særskilt problem for Vilstrup er dog, at man går glip af de hemmelige telefonnumre, som i dag udgør 16 pct. af samtlige telefonnumre. ${ }^{8}$

\section{Svarpersonen}

Når man i første trin har udvalgt et antal private husstande, er det næste problem, hvem man i andet trin skal interviewe inden for den enkelte husstand. ${ }^{9}$ Det nemmeste og billigste er naturligvis, at man interviewer den, som tager telefonen; mens en statistisk set mere korrekt løsning er at foretage en tilfældig udvælgelse blandt samtlige voksne husstandsmedlemmer, uanset om de er hjemme eller ej. Man kan for eksempel systematisk udvælge den voksne person, som først har fødselsdag, hvilket i praksis fungerer som tilfældig udvælgelse. Er vedkommende ikke hjemme, er der ikke andet for, end man må prøve at ringe på et senere tidspunkt. Denne fremgangsmåde bruges af både AIM og Gallup.

Det er min klare fornemmelse, at det lige præcis er her i andet trin, at det store dilemma ligger. Skal man vælge den nemme eller den dyre løsning? Det er endda ikke sikkert, at den dyre løsning er den mest hensigtsmæssige, hvis man vil have meningsmålingen gennemført $i$ løbet af să kort tid som muligt og samtidig gerne vil have en rimelig høj svarprocent. De forskellige analyseinstitutter har valgt forskellige løsninger. Greens har valgt den nemme løsning med at interviewe den, som tager telefonen, men forsvarer dette valg med, at eventuelle skævheder kan korrigeres i vejningsfasen, som vi senere kommer til. Vilstrup anvender det kriterium, at man ved to tredjedele af opkaldene interviewer den yngste tilstedeværende mand og i en tredjedel af opkaldende den 
yngste tilstedeværende kvinde. Herved kompenseres for det forhold, at det især er yngre og især mænd, som er sværest at træffe hjemme. Problemet med både Greens' og Vilstrups udvalgsmetode er, at man kun interviewer tilstedeværende personer. Den del af husstandens personer, som sjældent er hjemme, bliver derved underrepræsenteret.

Gallup anvender som nævnt fødselsdagskriteriet, uanset om vedkommende er hjemme ved forste opkald, og man har samtidig lost problemet med at gennemfore undersøgelser på kort tid på en ganske smart måde. Er den udvalgte person ikke hjemme ved den forste kontakt, sporger man om, hvornår vedkommende kan træffes, og man anvender om nødvendigt talrige genopkald over flere dage, indtil kontakten er etableret. Denne procedure anvendes dagligt, også i forbindelse med Gallups andre undersøgelser med telefoninterviews. Resultatet bliver derved, at der på en given dag interviewes såvel personer, der er nemme at få fat på, som personer, som man forst har fáet kontakt med efter talrige genopkald. Det bliver dermed muligt at gennemføre en meningsmåling i løbet af en dag eller to med såvel nemme som vanskelige kontakter, uanset at man har brugt mange dage på at få fat i de vanskelige kontakter. Lidt paradoksalt kan man sige, at Gallup først ved, hvad man vil spørge om, når kontakten er etableret.

Sonar arbejder som nævnt med et fast panel af svarpersoner, og i forbindelse med udvælgelse af nye medlemmer til panelet bruger man $\mathrm{i}$ første trin tilfældig udvælgelse af private husstande. I andet trin vælger Sonar en bestemt person i husstanden ud fra en regel, som skal sikre, at panelet forbliver repræsentativt. GfK har også et fast panel, men bruger en noget anden metode til udvælgelse af nye medlemmer. Faktisk anvender GfK en såkaldt kvote-udvælgelse, hvilket betyder, at man søger at opnå samme andel af forskellige befolkningsgrupper opdelt efter kommunetype, køn, alder, urbanisering, husstandsstørrelse eller lignende, som man har i hele befolkningen ifølge Danmarks Statistik. Denne metode er ellers ikke så positivt omtalt i metode-litteraturen, fordi der ikke er tale om ægte sandsynlighedsudvælgelse (se for eksempel Babbie, 1992: 231; Barnett, 1991: 131-132); men den kan bedre forsvares, jo flere kriterier der indgår ved opdelingen af befolkningen. GfK oplyser, at man i forbindelse med sine øvrige markedsundersøgelser med personlige interviews opmuntrer sine interviewere til at rekruttere svarpersoner, som man for tiden mangler i udvalget.

\section{Svarprocenten}

Ved svarprocenten forstås procentandelen af den oprindelige stikprøve, som faktisk fører til et gennemført interview (dvs. eksklusive ikke trufne og nægtere), og den bør naturligvis være så høj som mulig.

For GfK og Sonar, som anvender et fast panel, kan det være vanskeligt at definere den oprindelige stikprøve, men inden for panelet er svarprocenten normalt omkring 85 pct., hvilket må betegnes som høj. Det hører dog 1 hø) grad med til vurderingen af panelernes svarprocent, at der automatisk sker en udelukkelse af de personer, som er uvillige til at besvare postspørgeskemaerne. 
GfK oplyser, at det kun er maksimalt 35-40 pct. af de oprindeligt kontaktede personer, som indvilliger $\mathrm{i}$ at deltage i panelet, og at der er størst problem med at fastholde unge og karrieremennesker. For begge institutter gælder det, at svarpersonerne opmuntres med mindre præmiekonkurrencer til at blive i panelet, og hvis de ikke har svaret flere gange, bliver de telefonisk spurgt, om de ønsker at fortsætte i panelet.

Blandt de institutter, som anvender telefoninterviews, er der betragtelig variation i de oplyste svarprocenter. Lavest ligger Greens med cirka 60 pct. på trods af, at man foretager op til tre genopkald over to dage og i øvrigt blot interviewer den, som tager telefonen. Dernæst kommer Vilstrup og AIM med oplyste svarprocenter på 65-70 pct. Vilstrup har en indsamlingsperiode på totre dage, og hvor der ikke opnås kontakt, foretages der genopkald på den sidste dag. AIM foretager op til fem genopkald. I pressede situationer, hvor man for eksempel ønsker at gennemføre interviews på dagen for valgets udskrivelse eller dagen for valgets afholdelse, må man formode, at svarprocenten er lavere. ${ }^{10}$ For Gallup kan det på grund af den særlige indsamlingsform med daglige genopkald være vanskeligt at opgøre en eksakt svarprocent; men instituttet oplyser, at de i praksis ligger over 80 pct. også i forbindelse med éndags-indsamlinger.

Alt andet lige må man forvente et bedre resultat, jo højere svarprocent. Den værste situation, man kan være i, er, hvis man både har mange kontaktforsøg og en lav svarprocent, idet frafaldet da må formodes at være systematisk. Man kan således bedre tolerere en lav svarprocent, hvis indsamlingen foregår over få timer. I øvrigt må interviewernes træning og erfaring være af betydning for antallet af nægtere.

Uanset de forskellige svarprocenter ligger antallet af gennemførte interviews påfaldende ensartet for alle institutter omkring 1.100 interviews. Ved folketingsvalget i 1994 var der dog en tendens til flere interviews de sidste dage før valget. Gallup havde således 1.795 svar to dage før valget, og Vilstrup havde 1.491 svar dagen før valget. På selve valgdagen gennemførte AIM og Gallup endvidere såkaldte "exit polls" med vælgere, som allerede havde stemt, med henholdsvis $1.871 \mathrm{og} 2.344$ svarpersoner. AIMs undersøgelse var dog ikke en ren exit poll, da den påbegyndtes allerede dagen før valget.

\section{Udspørgningen}

Måden, man spørger på, har betydning for svaret. Det gælder også en forholdsvis simpel ting som partivalg. Institutterne lægger vægt på at understrege, at de ikke er ude på at lave egentlige prognoser for kommende folketingsvalg, men ønsker at måle partiernes øjeblikkelige tilslutning. Kun en eller to dage før valget spørger man, hvordan folk faktisk vil stemme. AIM anvender spørgsmålsformuleringen: "Hvilket parti ville De stemme på, hvis der var folketingsvalg i morgen?". Vilstrup giver med spørgsmålet: "Hvilket parti er det mest sandsynligt, at De ville stemme på, hvis der var folketingsvalg i morgen?" en mild tilskyndelse til at vælge et bestemt parti. Ikke mindst efter valget af løsgængeren Jacob Haugaard i september 1994 er det blevet noget kontroversielt 
at spørge om et bestemt parti, da det jo også er muligt at stemme på kandidater uden for partierne. Endelig er der også muligheden for at stemme blankt eller at afholde sig fra at stemme. For at holde alternativerne åbne sporger Gallup og Greens derfor: "Hvad ville De stemme, hvis der var folketingsvalg i morgen?"

Spørgsmålet kan måske lyde uskyldigt nok, men vil dog af nogle blive opfattet som provokerende på grund af valghemmeligheden, og dette kan føre til, at man enten nægter at medvirke eller svarer undvigende. Endvidere er der også en del, som ikke vil eller kan beslutte sig, eller som vakler mellem flere partier. Da man gerne vil have så mange som muligt til at oplyse partivalg, anvender nogle institutter en form for videre sondering. I tilfælde af et usikkert svar eller "ved ikke" tilføjer Gallup således: "Er der et parti, De hælder særligt imod?", og Vilstrup spørger: "Hvilke partier kunne eventuelt komme på tale?" Hvis svarpersonen fastholder to partier, registrerer Vilstrup begge svar, som derefter hver for sig tæller som en halv stemme i den endelige optælling. Greens prøver ikke at presse til valg af et bestemt parti, men for at sikre sig mod en særlig systematik i de usikre svar spørges, om man vil stemme enten borgerligt, venstrefløj eller andet. Endvidere har man hos Greens valgt at se bort fra stemmer på kandidater uden for partierne. Hos AIM indgår "tvivlere" ikke i partipræference-resultatet. Det er mit indtryk, at intet institut endnu har fundet en helt tilfredsstillende måde at hehandle tvivlere nå."

Da GfK og Sonar anvender postspørgeskemaer, er det ikke muligt at sondere og i stedet anvendes en anden fremgangsmåde. Først spørges, om svarpersonen ville stemme, hvis der var valg på en bestemt dato, og i bekræftende fald spørges om, hvilket parti man vil stemme på. Svarpersonen sætter derefter kryds på en liste over samtlige for tiden opstillingsberettigede partier inklusive den mulighed, at man stemmer blankt. På den måde tilskyndes svarpersonen til at vælge et bestemt parti. Svarsituationen har den fordel, at den minder mere om den situation, hvor man står i stemmeboksen; men den giver ikke mulighed for at nævne andre alternativer, såsom endnu ikke opstillede partier eller uafhængige kandidater uden for partierne.

\section{Vejningen}

Under vejningen bestemmes, med hvilken vægt den enkelte svarperson skal indgå $\mathrm{i}$ den endelige optælling. Princippet ved vejningen er at kompensere for skævheder i mængden af gennemforte interviews. Er for eksempel andelen af gennemforte interviews med svarpersoner fra Fyn kun halv så stor som andelen af fynske vælgere ifølge den officielle statistik, kompenseres for dette ved, at hver fynbo indgår med vægten to i den endelige optælling. I praksis kan vejningen være en problematisk proces, da man gerne på samme tid vil vægte med hensyn til flere forskellige demografiske kriterier, såsom geografisk region, køn, alder og husstandsstørrelse. Et problem er, at målingen bliver for usikker, hvis en bestemt undergruppe er al for underrepræsenteret og derfor skal tildeles en meget høj vægt. I vejningsprocessen kan indgå såvel ekspertvurderinger som anvendelse af edb-iterationsprocedurer. Under de fleste omstæn- 
digheder er det en fordel, at de gennemførte interviews er så repræsentative som muligt allerede for vejningen. ${ }^{12}$

Ud over den nævnte "demografiske vejning" kan en såkaldt "politisk vejning" komme på tale. Ved en politisk vejning forstås, at man også tager hensyn til, om svarpersonerne er politisk repræsentative. Dette gøres i praksis ved, at man spørger folk om, hvad de stemte ved sidste folketingsvalg, og sammenholder disse oplysninger med det faktiske valgresultat. Et problem er her, at svarpersonerne kan have vanskeligt ved at huske eller ikke ønsker at oplyse, hvad de gjorde ved sidste folketingsvalg. Dette problem undgår man i nogen grad med et fast panel af svarpersoner, hvor man tidligere har spurgt om partivalg. Så vidt jeg er orienteret, foregår den politiske vejning som en supplerende justering efter den demografiske vejning. ${ }^{13}$

Det er mit indtryk, at vejningen hos nogle institutter er en vigtig fase i meningsmålingen og derfor er mere fortrolig end andre faser $i$ undersøgelsen. Det er dog sikkert, at alle institutter i det mindste vejer efter de fire ovennæunte demografiske kriterier. Gallup oplyser, at den demografiske vejning har mindre betydning på grund af den høje svarprocent. I forbindelse med folketingsvalget i 1994 anvendte alle institutter, undtagen AIM, også politisk vejning. AIMs argument var, at der var gået for lang tid siden det forrige folketingsvalg i 1990, og at svarpersonernes oplysninger om tidligere partivalg derfor var for upålidelige.

\section{Konkluderende om metoderne}

Efter gennemgangen og sammenligningen af de enkelte analyseinstitutters metoder til politiske meningsmålinger tegner der sig følgende billede: Hvad enten man taler om undersøgelsestype, stikprøve, svarperson, svarprocent, udspørgning eller vejning, står et institut over for en række vanskelige valg, hvor ikke mindst økonomiske overvejelser kan have stor betydning. I praksis har de forskellige danske institutter valgt ret så forskellige løsninger, hvilket i sig selv gør meningsmålingerne interessante ud fra en metodisk synsvinkel.

Hvad angår valg af undersøgelsestype, har GfKs og Sonars paneler den fordel, at man til en vis grad undgår tilfældige svingninger mellem de enkelte målinger, samt problemet med at folk ikke kan huske, hvad de stemte ved sidste valg. Til gengæld sker der en selektering og påvirkning af paneldeltagerne, som gør dem mindre repræsentative.

I stikprøvens første fase, hvor husstandene udvælges, er der ikke de store forskelle, men det er formodentlig en marginal fordel for Gallup, Greens og Vilstrup, at de anvender stratificeret udvælgelse. Vilstrup har dog det problem, at man ikke får hemmelige telefonnumre med. Ved valg af svarperson inden for husstanden, kan man kritisere, at Greens og Vilstrups kun interviewer tilstedeværende personer; men Vilstrup søger dog at kompensere ved en særlig udvalgsregel. Udskiftningen i GfKs og Sonars paneler har helt eller delvis karakter af kvote-udvælgelse med dertil knyttede problemer.

Alle institutter oplyser, at de gør en del ud af genopkald og tilskyndelse til svar; men de oplyste svarprocenter med cirka 60 pct. for Greens, 65-70 pct. 
for Vilstrup og AIM, samt over 80 pct. for Gallup taler deres tavse sprog. De høje svarprocenter omkring 85 pct. for GfKs og Sonars paneler skal ses i lyset af den omtalte selektering.

Det største problem i forbindelse med udspørgningen er, hvad man skal gore med svarpersoner, som er i tvivl om, hvad de ville stemme. Gallup og Vilstrup giver en mild tilskyndelse til at oplyse et bestemt parti, og Vilstrup registrerer endvidere vaklen mellem to partier. AIM og Greens ser bort fra tvivlere, men Greens kontrollerer dog, om tvivlerne hælder til en bestemt side. Det ser ud til, at intet institut endnu har fundet den ideelle måde at behandle tvivlere på. På grund af undersøgelses- og spørgeformen har GfK og Sonar et ringe antal tvivlere.

I den afsluttende vejningsfase har den demografiske vejning formentlig større betydning, jo mere det enkelte institut er gået på kompromis i udvalgsfasen, og jo lavere svarprocenten er. Ved den politiske vejning har GfK og Sonar den fordel fremfor de andre institutter, at de har mere pålidelige oplysninger om tidligere stemmeadfærd.

Et aspekt, som jeg kun har været overfladisk inde på i gennemgangen af institutternes metoder, er spørgsmålet om de enkelte institutters grundighed og konsekvens i den praktiske gennemførelse. Man kunne tale om det enkelte instituts grad af professionalisme og effektiv management i den praktiske gennemførelse af undersøgelser, herunder træning, anvarliggørelse og overvågning af interviewere og øvrige medarbejdere, samt ikke mindst løbende opsamling af erfaring ved egne undersøgelser og ved at følge med i den faglige litteratur og debat. I sagens natur kan jeg ikke sige meget om dette aspekt ud over, at jeg gennem mine kontakter til de enkelte institutter generelt har fået et positivt indtryk.

\section{Resultatet}

Som nævnt fastholder analyseinstitutterne, at de almindelige meningsmålinger ikke er prognoser for et kommende folketingsvalg, med mindre man direkte spørger folk om, hvordan de faktisk vil stemme. Jeg vil dog alligevel mene, at det er en rimelig forventning, at målingen af partiernes tilslutning skal nærme sig det faktiske valgresultat, jo nærmere man kommer valgdatoen. Det er derfor et "sandhedens øjeblik", når man giver sig til at sammenligne det faktiske valgresultat med de seneste meningsmålinger. Uanset hvad man kan fremføre af metodiske problemer hos det enkelte analyseinstitut, er det trods alt resultatet, der tæller.

Men hvordan skal man sammenligne meningsmålingerne med det faktiske resultat? Berlingske Tidende bragte efter valget i 1994 (henholdsvis 23/9 og 24/9) to forskellige artikler, som gav forskelligt svar på, hvilket institut der kom tættest på valgresultatet. Den forste var skrevet af universitetsforskeren Hans Jørgen Nielsen, som konkluderede, at GfKs Observa måling kom tættest på; mens den anden var udsendt af Gallup instituttet og konkluderede - măske ikke så overraskende - at Gallup var vinderen. Forklaringen er selvfølgelig, at der var anvendt forskellige beregningsprincipper i de to artikler. 
Hans Jørgen Nielsen anvendte det princip, at han så bort fra stemmer på kandidater uden for partierne og sammenlignede den rene partifordeling i den enkelte meningsmåling med den rene partifordeling i det faktiske valgresultat. Den enkelte målings afvigelse fra valget beregnes ved en såkaldt "fejlsum", dvs. summen af procentafvigelserne for de enkelte partier, uanset om fortegnet er positivt eller negativt.

Gallup valgte i stedet at medtage stemmer uden for partierne, og afvigelsen beregnes med et såkaldt "chi-i-anden" mål. Dette mål er også en slags fejlsum, men det enkelte bidrag beregnes ved den kvadrerede forskel mellem målingen og valget, divideret med tilslutningen ved valget. Til forskel fra den førnæunte fejlsum straffer Gallups mål i højere grad store afvigelser samt afvigelser for små partier. ${ }^{14}$

\section{Folketingsvalget 1994}

De enkelte meningsmålinger, der blev publiceret efter valget var udskrevet den 29/8 1994, er vist i tabel 2 på næste side. I tabellen er kun medtaget meningsmålinger, som er uafhængige af hinanden. Gallup foretog fra den 25/8 daglige indsamlinger og publicerede fra den $30 / 8$ hver dag en måling, som byggede på de foregående fire dages indsamlinger. Da denne præsentationsform kan skabe en kunstig kontinuitet, er valgt kun at medtage målinger, som ikke overlapper. Tilsvarende er ikke medtaget en måling fra AIM den 20/9, som også indgik som en del af AIMs exit poll, der blev vist i TV2 på valgdagen. ${ }^{15}$ Selv med denne begrænsning satte valgkampen i 1994 Danmarksrekord i antal publicerede meningsmålinger.

Tabellen viser for hver af de 19 uafhængige målinger: dato for offentliggørelse, dato for start og slutning på indsamlingsperioden, samt midtpunktet $\mathrm{i}$ indsamlingsperioden. Målinger med samme start- og slut-dato er altså gennemført på en enkelt dag. Under stemmefordelingen er anført eventuel oplyst stikprøvestørrelse, gennemførte interviews samt afgivne "stemmer", forstået som tilkendegivelse af, hvad man ville stemme. Det var noget skuffende, at det kun var Sonar og Vilstrup, som publicerede andet end antal gennemforte interviews (GfK har senere oplyst svarprocent m.v. til mig). AIM publicerede dog også procent gennemførte interviews i forbindelse med sin måling den 28/8. Disse tal illustrerer nogle vigtige pointer. Sammenligner man således procent afgivne stemmer hos Sonars og GfKs paneler på den ene side med Vilstrups og AIMs telefoninterviews på den anden side, fremgår det klart, at panel-deltagerne $\mathrm{i}$ meget højere grad har besluttet, hvad de vil stemme end tilfældigt udvalgte vælgere. Ser man endvidere på udviklingen i Vilstrups interviews, fremgår det lige så klart, at den procent, som angiver, hvad de ville stemme, stiger markant $i$ løbet af valgkampen.

Det var tilfredsstillende, at samtlige institutter for forste gang publicerede stemmefordelingen med én decimals nøjagtighed, også for de små partier. ${ }^{16}$ Tallene viser, at valgkampen var kendetegnet ved overvejende stabilitet i partiernes tilslutning. Socialdemokratiet viste en tendens til stigende tilslutning frem til omkring midten af valgkampen, efterfulgt af en vigende tendens, og $\mathrm{CD}$ viste omtrent det modsatte forløb. Mest markant var en tendens til sti- 
Tabel 2. Meningsmálinger op til folketingsvalget 21/9 1994

\begin{tabular}{|c|c|c|c|c|c|c|c|c|c|c|}
\hline Institut & Gallup & GFK & AIM & Gallup & Sonat & Gallup & Vilstrup & Greens & Sonat & Gallup \\
\hline Avis & Berl.T. & B.T. & J̦̣ll.P. & Betl.T. & Jyll.P. & Bert.T. & Polit. & Borsen & J̣ll.P. & Berl.T. \\
\hline Offentl.g. & $30 / 08$ & $01 / 09$ & 3008 & 0409 & 0409 & 0809 & $08: 09$ & $08 / 09$ & $11 / 09$ & 1209 \\
\hline Start & $25 / 08$ & 2708 & $29 ; 08$ & 3008 & 0109 & 0309 & 0409 & 05,09 & 0709 & 0709 \\
\hline Slut & $28: 08$ & 2708 & $29 / 08$ & $02 / 09$ & $01 / 09$ & 0609 & $05 / 09$ & 06,09 & $07 / 09$ & $10: 09$ \\
\hline Midt & $26 / 08$ & $2 \pi 08$ & $29 / 08$ & $31 / 08$ & 0109 & 0409 & 0409 & 0509 & $07 / 09$ & 08.09 \\
\hline A Sociald. & 34.0 & 32.4 & 33.9 & 34.5 & 31.5 & 37.3 & 36.1 & 33.8 & 34.1 & 33.5 \\
\hline B Radikale & 4.7 & 5.2 & 3.5 & 3.7 & 4.1 & 4.3 & 2.9 & 3.7 & 5.0 & 3.9 \\
\hline C Konsersative & 13.9 & 15.8 & 17.5 & 15.3 & 13.5 & 14.1 & 17.6 & 17.7 & 13.4 & 13.3 \\
\hline D CD & 2.8 & 1.5 & 1.1 & 2.1 & 2.2 & 1.5 & 1.8 & 2.2 & 1.9 & 2.2 \\
\hline F SF & 10.8 & 8.3 & 9.9 & 10.1 & 10.5 & 9.8 & 9.9 & 9.2 & 10.2 & 11.5 \\
\hline Q KRF & 1.9 & 2.2 & 0.7 & 1.7 & 2.0 & 2.0 & 2.9 & 2.1 & 2.0 & 1.9 \\
\hline V Venstre & 23.0 & 24.0 & 26.1 & 23.0 & 25.2 & 21.9 & 21.0 & 23.2 & 22.9 & 23.9 \\
\hline Z Fremskr.P. & 6.3 & 7.9 & 5.3 & 7.2 & 8.7 & 6.5 & 5.9 & 6.5 & 8.2 & 7.5 \\
\hline (0 Enh.listen & 0.4 & 2.7 & 1.0 & 0.7 & 2.3 & 1.2 & 0.9 & 1.7 & 2.3 & 1.9 \\
\hline Andre & 2.2 & 0.0 & 1.0 & 1.7 & 0.0 & 1.4 & 1.0 & 0.0 & 0.0 & 0.4 \\
\hline Sum & 100.0 & 100.0 & 100.0 & 100.0 & 100.0 & 100.0 & 100.0 & 100.1 & 100.0 & 100.0 \\
\hline Stikprove & & 1353 & & & 1450 & & 1632 & & 1515 & \\
\hline Gennemf. N & 1150 & 1140 & 1050 & 1136 & 1153 & 1130 & 1022 & 1016 & 1201 & 1201 \\
\hline Gennemf. \% & & 84 & 68 & & 80 & & 63 & & 79 & \\
\hline Afgivne stemmer & & 1098 & & & 1114 & & 787 & & 1168 & \\
\hline Afgivne st. \% & & 96 & & & 97 & & 77 & & 97 & \\
\hline Abs.afs: & 4.80 & 4.90 & 7.90 & 4.60 & 7.50 & 5.80 & 7.70 & 4.85 & 5.20 & 5.90 \\
\hline Forv. abs.afi: & $(3.26)$ & $(3.27)$ & (3.41) & $(3,28)$ & $(305)$ & $(328)$ & $(363)$ & $(346)$ & (208) & 2109 \\
\hline & & & & & & & \multicolumn{4}{|c|}{ EXIT POLLS } \\
\hline Institut & GIK & Vilstrup & Gallup & Greens & Sonar & Gallup & Vilstrup & AIM & Gallup & \\
\hline Avis & B.T. & Polit. & Berl.T. & Bersen & Jyll.P. & Berl.T. & Polit. & TV2 & DR & \\
\hline Offentl.g. & 16,09 & $15 / 09$ & 1609 & 16109 & $18 / 09$ & $20 / 09$ & 2!/09 & $21 / 09$ & $21 / 09$ & \\
\hline Start & 10,09 & $11 / 09$ & $11 / 09$ & 1309 & $14 / 09$ & $15 / 09$ & $20 / 09$ & $20 ; 09$ & $21 / 09$ & Faktisk \\
\hline Slut & 1009 & $13 / 09$ & $14 / 09$ & 1409 & $14 / 09$ & 18,09 & $20 / 09$ & $21 / 09$ & $21 / 09$ & FV94 \\
\hline Midt & 10,09 & $12 / 09$ & $12 / 09$ & $13 / 09$ & 1409 & 1609 & $20 / 09$ & $20 / 09$ & $21 / 09$ & 2109 \\
\hline Sociald. & 34.2 & 35.7 & 34.3 & 35.3 & 32.3 & 34.2 & 35.8 & 34.4 & 34.7 & 34.6 \\
\hline B Radikale & 4.6 & 4.4 & 4.2 & 4.4 & 4.8 & 4.0 & 4.2 & 5.6 & 4.1 & 4.6 \\
\hline C Konservative & 15.4 & 15.5 & 15.3 & 15.5 & 14.1 & 13,4 & 15.6 & 15.5 & 14.8 & 15.0 \\
\hline D CD & 2.1 & 1.7 & 2.1 & 2.1 & 2.8 & 3.1 & 4.1 & 2.8 & 3.3 & 2.8 \\
\hline F SF & 9.1 & 9.4 & 8.5 & 8.8 & 9.6 & 9.0 & 6.7 & 8.0 & 7.2 & 7.3 \\
\hline Q KRF & 1.9 & 1.0 & 2.3 & 2.6 & 1.8 & 1.9 & 2.0 & 2.0 & 2.1 & 1.9 \\
\hline V Venstre & 22.3 & 22.4 & 23.6 & 21.7 & 22.4 & 24.5 & 20.1 & 23.8 & 22.4 & 23.3 \\
\hline Z Fremsks.P. & 7.0 & 5.8 & 6.6 & 8.0 & 7.5 & 6.2 & 6.0 & 4.3 & 6.4 & 6.4 \\
\hline 0 Enh.listen & 3.4 & 2.7 & 2.1 & 1.6 & 4.7 & 2.9 & 3.7 & 2.9 & 3.6 & 3.1 \\
\hline Andre & 0.0 & 1.4 & 1.0 & 0.0 & 0.0 & 0.8 & 1.8 & 0.7 & 1.4 & 1.0 \\
\hline Sum & 100.0 & 100.0 & 100.0 & 100.0 & 100,0 & 100.0 & 100.0 & 100.0 & 100.0 & 100.0 \\
\hline Stikprove & 1409 & 1632 & & & 1527 & & 2352 & & & \\
\hline Gennemf. $\mathrm{N}$ & 1146 & 1024 & 1539 & 1028 & 1232 & 1795 & $149 !$ & 1871 & 2344 & \\
\hline Gennemf. $\%$ & 81 & 63 & & & 8! & & 63 & & & \\
\hline Afgirne stemmer & 1123 & 850 & & & 1206 & & 1327 & & & \\
\hline Aigunest. \% & 98 & 83 & & & 98 & & 89 & & & 84 \\
\hline Aos.añ & $5 . i v$ & 4.10 & 2.40 & 2.00 & 5.20 & 3.20 & 4.60 & 2.80 & 1.70 & 0.00 \\
\hline Fon: abs.aft: & (3.26) & $(3.49)$ & (2.81) & (3.44) & (2.93) & $(2.61)$ & $(2.79)$ & (2.55) & $(2.28)$ & \\
\hline
\end{tabular}


gende tilslutning for Enhedslisten i løbet af valgkampen. Det er vigtigt at lægge mærke til, at de tre institutter GfK, Greens og Sonar konsekvent har 0 pct. i gruppen "Andre", dvs. stemmer uden for de opstillingsberettigede partier. Som det fremgik af den metodiske gennemgang, var der her tale om et bevidst valg, som ikke tidligere har haft nogen særlig betydning; men med valget af løsgængeren Jacob Haugaard er dette valg blevet mere problematisk. Der er dog ikke noget, der tyder på, at nogen af de øvrige institutter faktisk havde forudset, at specielt Jacob Haugaard ville blive valgt.

I den næstnederste linje har jeg anført mit eget mål for den enkelte målings afvigelse fra det faktiske valgresultat, kaldet "Abs.afv." (absolut afvigelse). Der er stort set tale om den samme fejlsum, som Hans Jørgen Nielsen anvendte; dog indgår også stemmer på kandidater uden for partierne. Ved at dividere fejlsummen med to får man endvidere den enkle fortolkning, at den absolutte afvigelse er den andel af stikprøvens stemmer, som skal flyttes for at give samme fordeling som det faktiske valgresultat - "Abs.afv." angiver altså procent "forkert" placerede stemmer. ${ }^{17}$ Jeg foretrækker dette mål fremfor Gallups version af chi-i-anden, som efter min mening er for sensitivt over for de små partiers afvigelse. I den nederste linje har jeg anført den forventede værdi af "Abs.afv." ud fra den antagelse, at der var tale om en simpel tilfældig stikprøve af det faktiske valgresultat. ${ }^{18}$ Denne værdi gør det muligt at vurdere, hvor stor betydning antal gennemførte interviews har for "Abs.afv."

Figur 1 øverst på næste side viser meningsmålingernes udvikling $\mathrm{i}$ absolut afvigelse fra det faktiske valgresultat.

Selv om der ikke var de store ændringer i partiernes tilslutning under valgkampen, viser figur 1 alligevel en tydelig tendens til, at målingerne nærmer sig det faktiske valgresultat, svarende til en absolut afvigelse på 0 , jo nærmere man kommer på valgdatoen. Den seneste måling, der var en exit poll, som Gallup foretog på selve valgdagen, kom med en afvigelse på 1,7 pct. fejlplacerede stemmer meget tæt på det faktiske valgresultat. Faktisk lå denne værdi lavere end den forventede på 2,28 ud fra den antagelse, at der var tale om en simpel tilfældig stikprøve. Forklaringen må være, at Gallups stratificerede udvalg fungerede bedre end et simpel tilfældigt udvalg, samtidig med at den øvrige metodiske praksis var i orden. AIMs delvise exit poll fra 20-21/9 lå med en afvigelse på 2,8 pct. ligeledes tæt på valgresultatet. På grund af en lidt mindre stikprøve end Gallup skulle man forvente en lidt større afvigelse. Dette var også tilfældet, men den faktiske afvigelse lå yderligere ganske lidt over den forventede afvigelse på 2,55 pct.

Ser man nærmere på de øvrige meningsmålinger, som ikke var exit polls, var det også Gallup, som kom nærmest på valgresultatet ved målingen fra 11-14/9, som med en afvigelse på 2,4 lå under en forventet simpel tilfældig afvigelse på 2,81 pct. Det hører dog med til historien, at Gallups senere måling fra 15-18/9 havde lidt større afvigelse, samt at målingen fra 7-10/9 var omtrent dobbelt så stor som forventet.

Af de øvrige institutter var det særligt GfK, der udmærkede sig med en tidlig måling fra 10/9, som havde en afvigelse under forventet. Dette er impone- 
Figtur 1. Absolut afvigelse fra fra FV 94

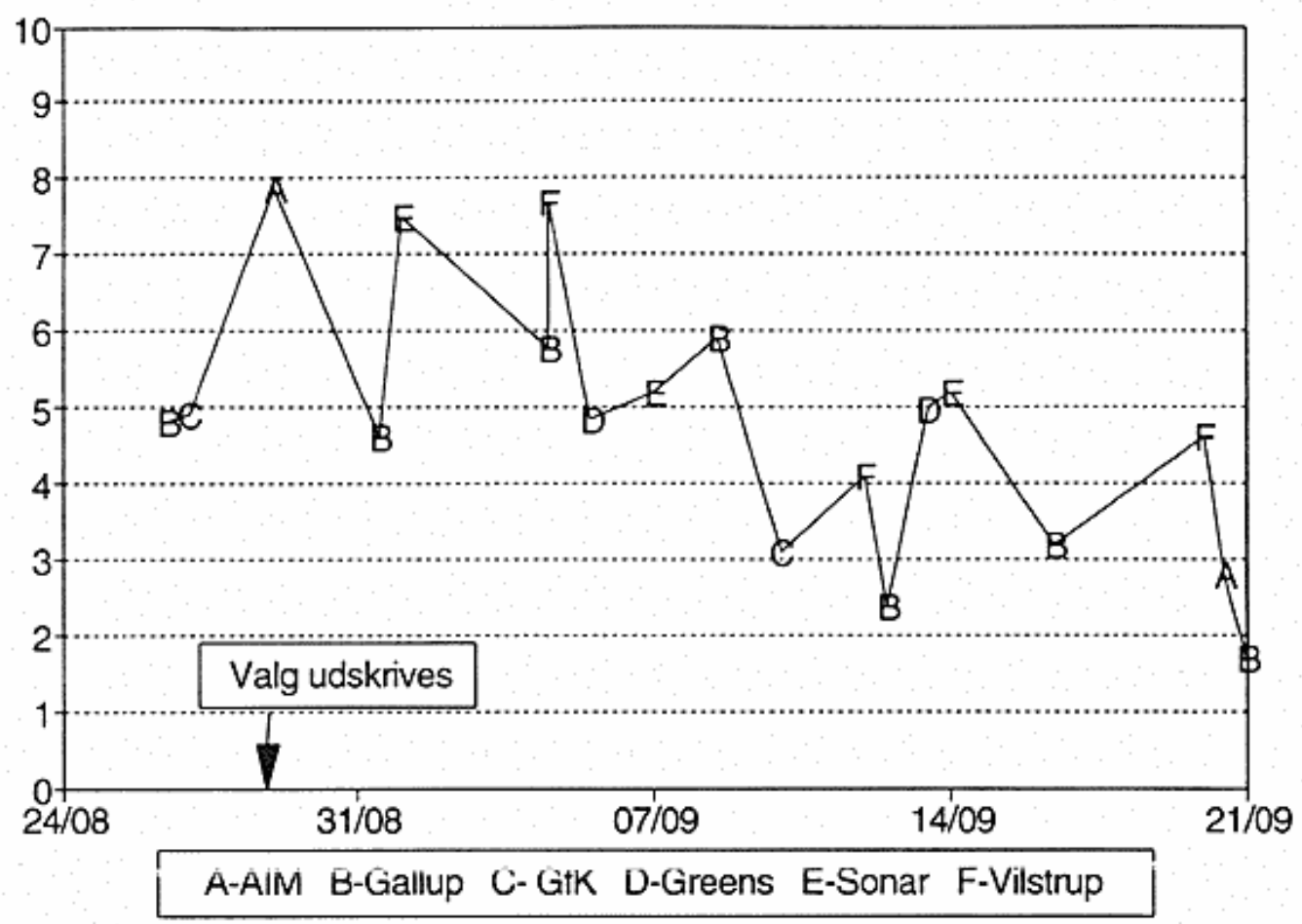

rende i betragtning af, at GfK så bort fra stemmer uden for partierne. GfK lå sammen med Gallup også rimelig tæt på det endelige valgresultat allerede før valgets udskrivelse. En medvirkende forklaring på GfKs gode resultater kan være, at man beholder sine svarpersoner tre-fire år i panelet, og at man derfor havde færre problemer med at fastslå, hvad de stemte tilbage i 1990.

Resten af institutterne havde gennemgående målinger, som adskilte sig noget mere fra det endelige resultat, dog aldrig mere end ca. det dobbelte af den forventede afvigelse. En del af disse større afvigelser lå endvidere mere end to uger for valgdatoen, og kan derfor forklares med reelle ændringer i partiernes tilslutning i løbet af valgkampen. Inden for knap to uger før valget lå afvigelserne i området to-fem pct., mens de tidligere målinger havde afvigelser i området fem-otte pct. Det er bemærkelsesværdigt, at resultaterne fra Greens, hvis metoder ovenfor blev fremstillet som mest problematiske, ikke klarede sig markant dårligere end de øvrige institutter.

Konklusionen på valgkamp 1994 mâ være, at alle målinger lå rimelig tæt på det faktiske valgresultat inden for to uger før valgdatoen, selv om afvigelserne $i$ de fleste tilfælde var lidt større end stikprøve-usikkerheden. Specielt de to exit polls af Gallup og AIM var tæt på det endelige resultat med Gallun som vinder. Ved de ovrige målinger klarede Gallup og GfK sig bedst, men Gallup havde dog midt i perioden afvigelser, som lå på niveau med de øvrige institutter. Før jeg diskuterer institutternes resultater i lyset af deres metoder, vil jeg 
se nærmere på resultaterne i de øvrige valgkampe siden 1984. Valgene vil blive gennemgået $\mathrm{i}$ omvendt kronologisk rækkefølge, da institutterne ved de seneste valg i højere grad brugte samme metoder som i 1994.

\section{Folketingsvalget 1990}

Under valgkampen op til folketingsvalget i 1990 foretog de samme institutter som i 1994 bortset fra AIM i alt 13 uafhængige meningsmålinger, altså væsentlig færre målinger end i 1994. Så vidt jeg er orienteret, var de anvendte metoder omtrent de samme som i 1994. Dog kunne GfK gennemføre en undersøgelse dagen før valget samtidig med Gallup og Vilstrup ved at telefoninterviewe panel-deltagerne i stedet for at anvende postspørgeskema. Figur 2 viser udviklingen i målingernes afvigelse fra det faktiske valgresultat.

Også her var den sidste Gallup-måling tæt på valgresultatet, og den absolutte afvigelse på 2,5 pct. var mindre end den forventede afvigelse på 2,82 pct., hvis der havde været tale om en simpel tilfældig afvigelse. De øvrige afvigelser, inklusive Gallups, lå inden for de to sidste uger før valget på omkring fem pct. En bemærkelsesværdig undtagelse var Greens, der knap en uge for valget havde en afvigelse på kun 3,3 pct. i forhold til en forventet afvigelse på 3,51 pct. Endvidere havde Greens allerede omkring to uger før valget en afvigelse, som var lidt mindre end de øvrige institutter. Dette sætter endnu en gang spørgsmålstegn ved de kritiske bemærkninger omkring Greens metoder.

Figur 2. Absolut afvigelse fra fra FV 90

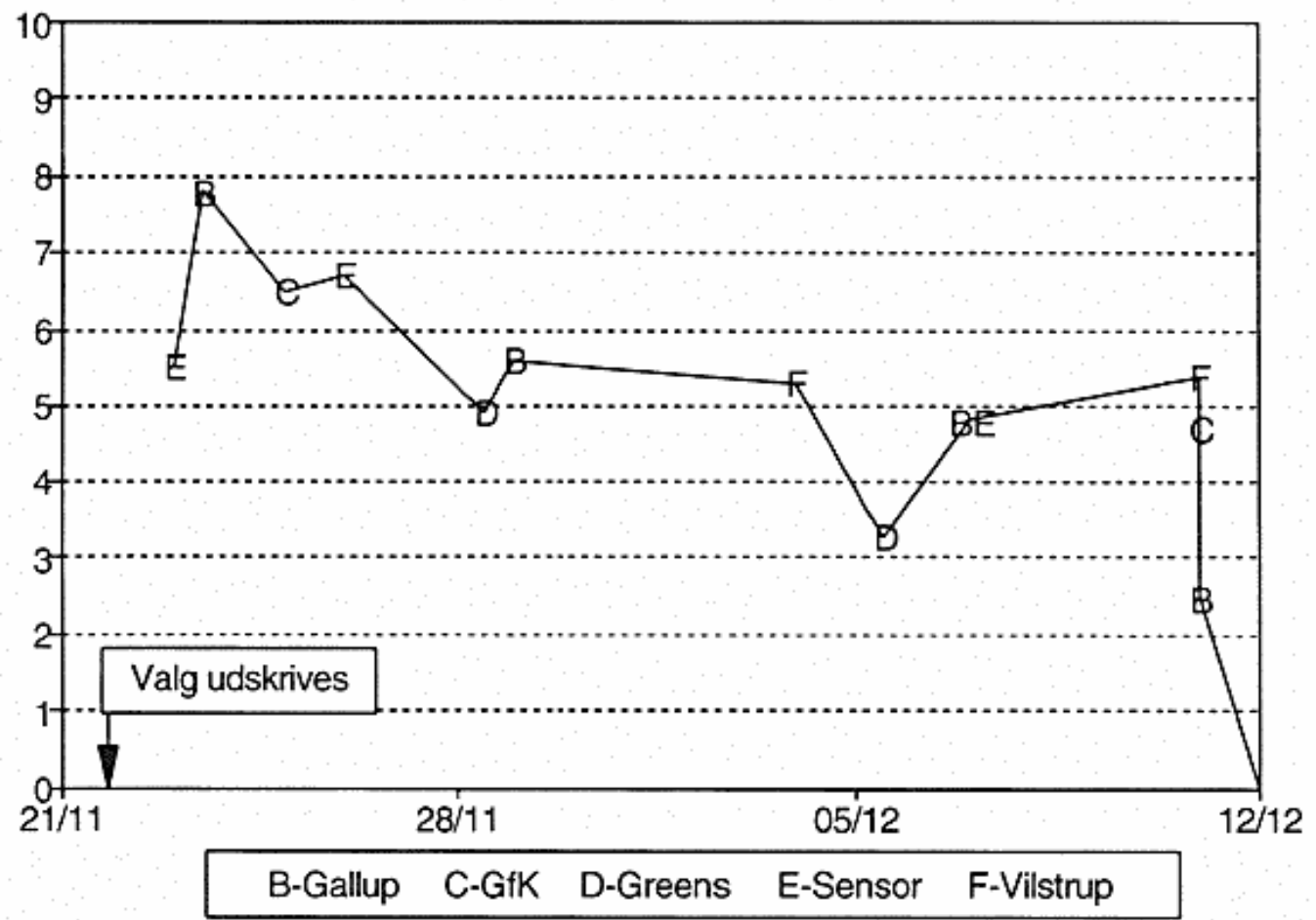




\section{Folketingsvalgene 1984, 1987 og 1988}

Resultaterne fra de tre folketingsvalg fra 1984 til 1988 vil kun blive kortfattet omtalt. Figur 3-5 viser de sædvanlige kurver for målingernes afvigelser. 1988valget var det forste valg, hvor Gallup anvendte telefoninterviews dagen for valget, og de kom endnu en gang tættest på valgresultatet, men kun en anelse bedre end Vilstrup. I både 1984 og 1987 lå Gallups målinger så langt tilbage i tiden, at de næsten er uden interesse. Til gengæld kappedes AIM, Observa og Vilstrup på omtrent samme afvigelses-niveau omkring fire-fem pct. om at komme tættets på valgresultatet.

\section{Konkluderende om resultater og metoder}

Hovedindtrykket af perioden 1984 til $1994 \mathrm{er}$, at alle institutter kom rimelig tæt på valgresultatet inden for de to sidste uger inden valgdatoen, typisk på et niveau omkring fire-fem pct. fejlplacerede stemmer. Afvigelserne har dog gennemgående været på et lidt højere niveau, end man teoretisk skulle forvente, hvis der var tale om simpel tilfældige stikprøver af det faktiske valgresultat. Dette kan ikke undre, når man tænker på de mange metodiske problemer, der skal løses for at tilnærme sig denne teoretiske ideal-situation. Så meget mere imponerende er det, at enkelte institutter i enkelte tilfælde har publiceret meningsmålinger, som havde afvigelser under forventet.

Figur 3. Absolut afvigelse fra FV 88

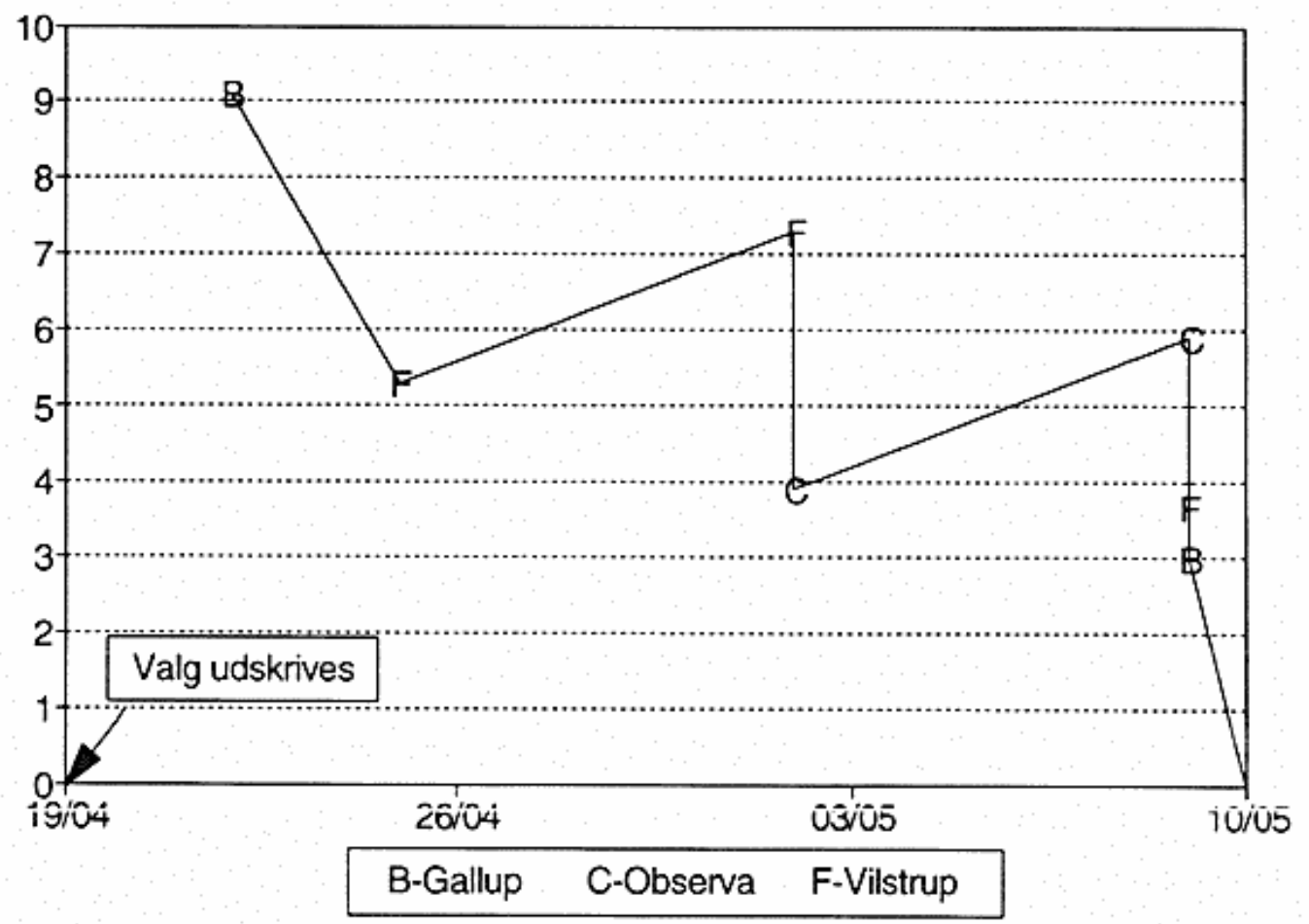


Figur 4. Absolut afvigelse fra FV 87

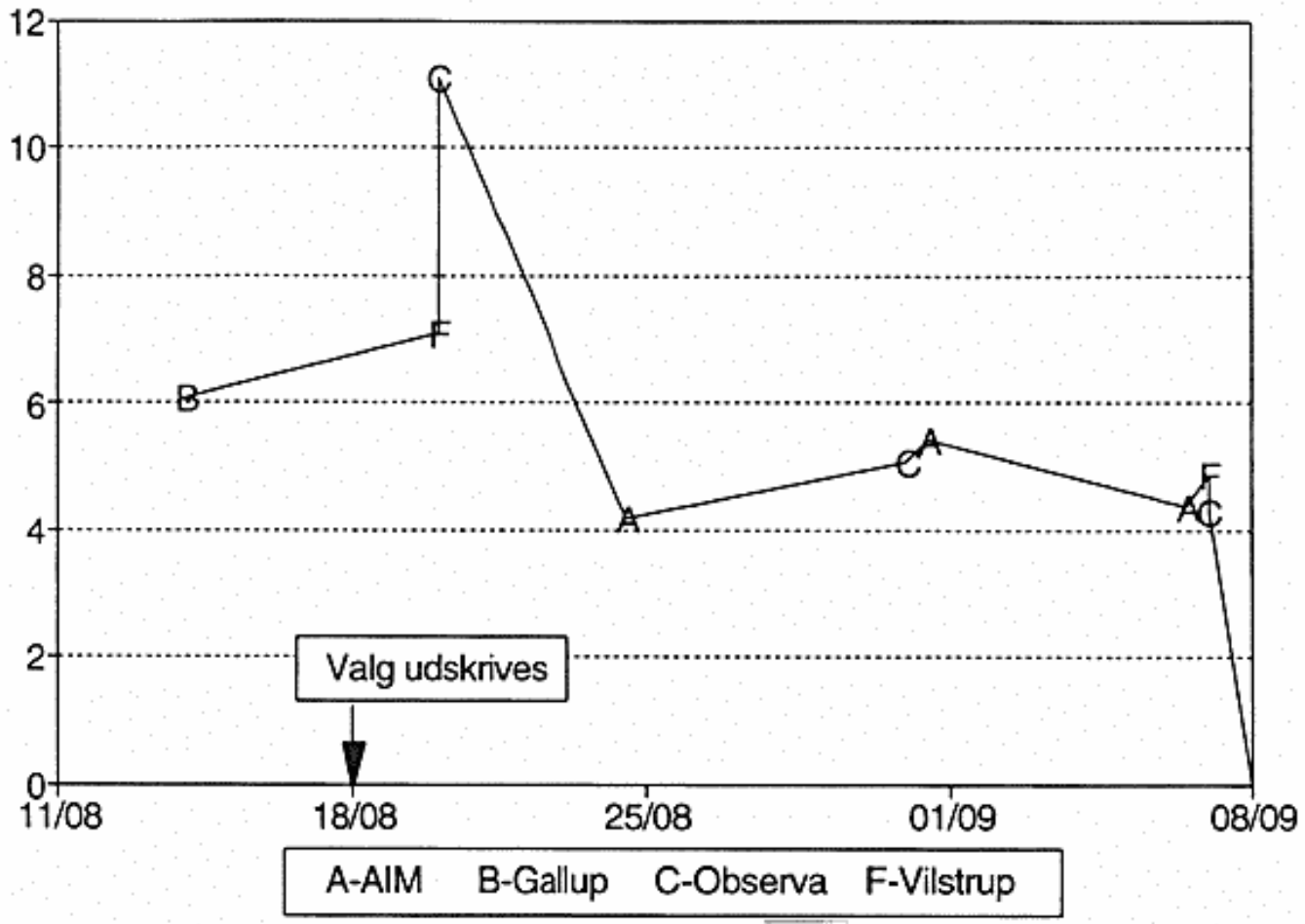

Figur 5. Absolut afvigelse fra FV 84

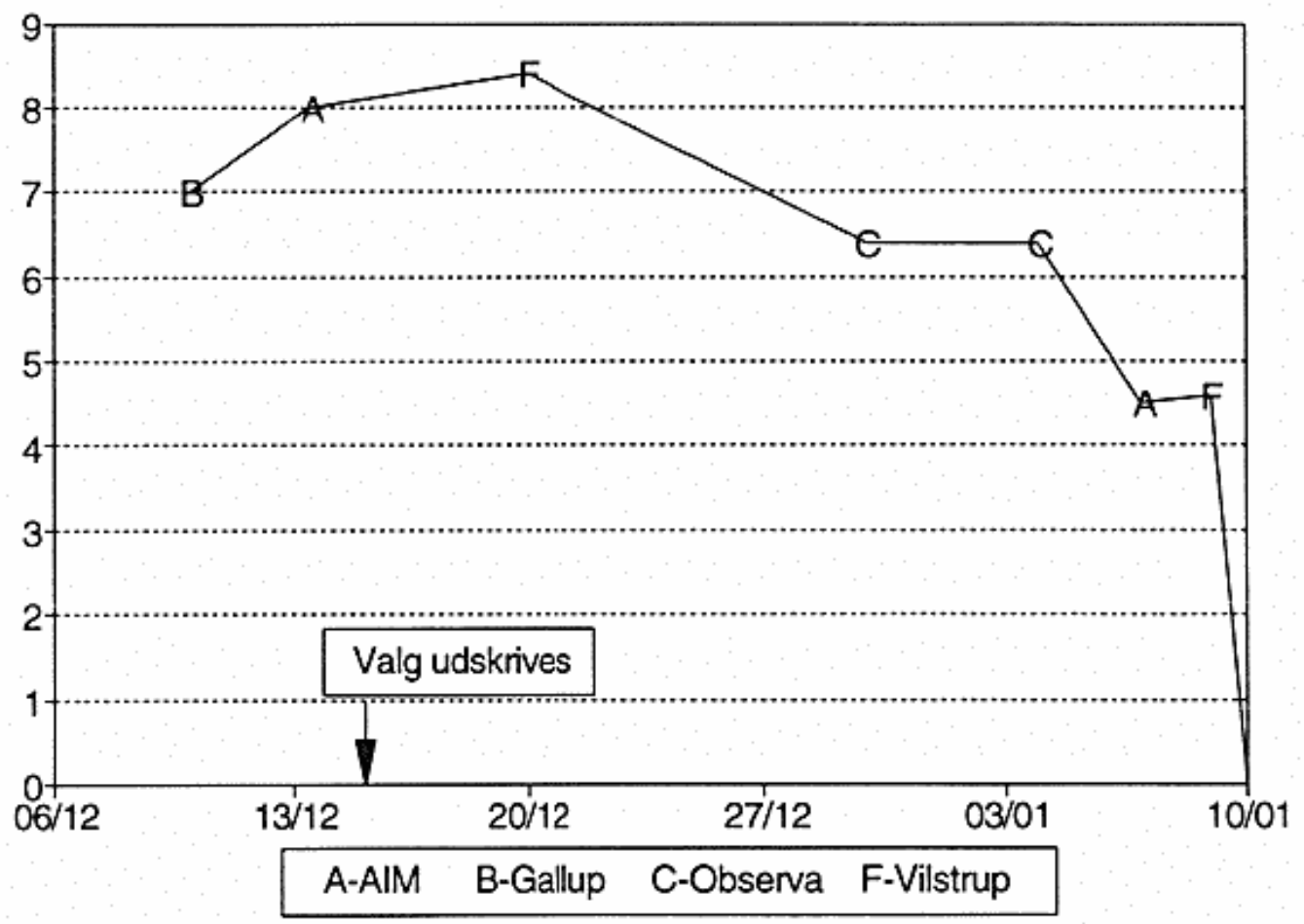


Gallup har ved de seneste tre folketingsvalg været tættest på det faktiske valgresultat ved den seneste måling, enten på selve valgdagen eller dagen for. Den mest nærliggende forklaring på dette flotte resultat er, at Gallups metodiske fremgangsmåde lever op til alle de krav, man med rimelighed kan stille. Ikke mindst er Gallups fremgangsmåde i forbindelse med genopkald en effektiv måde at løse problemet med lave svarprocenter ved undersøgelser, som gennemføres i løbet af enkelt dag på.

Jeg vil dog ikke undlade at dryppe enkelte dråber malurt i lykønskningsbægeret til Gallup. For det første er det tænkeligt, at det kun er meget tæt på valgdatoen, at Gallups spørgeteknik giver helt gyldige resultater. Som nævnt er der en hel del vælgere, som forst beslutter sig sent i valgkampen, og det er et problem, hvordan man skal udspørge svarpersoner, som er i tvivl. For det andet ser det ud til, at de gode resultater er opnået ved en ekstra indsats op til selve valgdatoen blandt andet ved et ekstra stort antal interviews. Yderligere tyder stigningen i antal gennemførte interviews op til den afgørende dag på, at Gallup allerede i god tid har intensiveret forsøgene på at få kontakt med en stor gruppe svært tilgængelige svarpersoner på selve dagen. Dette er i sig selv al ære værd, men det sætter samtidig spørgsmålstegn ved størrelsen af fejlmargenen ved Gallups øvrige målinger.

Ser man bort fra valget i 1994, var der således ingen klar tendens til, at Gallup ved de tidligere målinger var bedre end de øvrige institutter, som alle klarede sig omtrent lige godt, på trods af at nogle fik mere kritiske bemærkninger end andre under gennemgangen af metoderne. I 1994 havde Gallup i fire ud af seks tidlige målinger imidlertid mindre afvigelser end de fleste ovrige institutter. Kun GfK klarede sig lige så godt. En mulig forklaring kan være, at Gallup nu også har fảet løst de metodiske problemer med de tidlige interviews. Det næste folketingsvalg vil formodentlig give svaret på dette spørgsmål.

\section{Noter}

1. I forbindelse med en virksomhedsfusion i 1990 andrede Observa instituttet navn til GfK Danmark A/S, men deres meningsmálinger betegnes stadig som Observa mảlinger. Sonar hed oprindeligt Sensor, men skiftede på grund af en navnestrid til det nuvarende navn i 1991.

2. Som refereret i Avisärbogen, 1974-92. De seneste ằ er oplysningerne hentet direkte fra avisernes publicering af meningsmàlingerne.

3. Kontaktpersonerne var underdirekter Gregers Lyster fra AIM/Nielsen A/S, analysechef Soren C. Bjulf fra Gallup A/S, lektor Marcus Schmidt fra GfK Danmark A/S (Observa), analytiker Jens Nicolaisen fra Greens Analyseinstitut, direkter Gunnar Sehested Larsen fra Sonar, Institut for Markeds- og Opinionsanalyser, og direkter Kasper Vilstrup fra Vilstrup Research. Efter ustruktererede telefoninterviews med kontaktpersonerne sendte jeg dem en skriftlig beskrivelse af deres eget instituts metoder til politiske meningsmàlinger, som de derefter havde lejlighed til at korrigere og eventuelt supplere, hvilket alle benỵtterde sig of I denne artikel har jeg cammenckerpar onlyeningerne fra de ckriftlige heskrivelser af metoderne. Alle har haft mulighed for at kommentere artiklen, hvilket ledte til nogle mindre korrektioner.

4. Op til folketingsvalget i september 1994 foretog AIM meningsmàlinger for TV2, fyllands-Posten og Ugibrever Mandag Morgen. 
5. I situationer, hvor en undersøgelse skal gennemfores i løbet af en enkelt dag eller to, foretager GfK og Sonar telefoninterviews med paneldeltagerne.

6. Man skal dog vare opmarksom pả, at tilfaldighedsbegrebet $\mathrm{i}$ forbindelse med stikprover har en meget mere præcis betydning end $\mathrm{i}$ daglig tale. Hvis stikprøven er korrekt udtaget (og frafaldet ikke er skæut fordelt), kan man ved hjxelp af statistikkens teori angive, inden for hvilke granser stikproven med en given sikkerhed vil afvige fra den bagvedliggende population (se for eksempel Barnett, 1991).

7. CATI = "Computer Aided Telephone Interviewing" er nærmere omtalt i Blunch (1994: 141).

8. Procent hemmelige telefonnumre er beregnet efter henvendeise til alle telefonselskaber. Inden for KTASs område var procenten 19, mens den for de ovrige områder lå på 11-12 pct. Vilstrup mener ikke, at problemet er så stort, da en hel del hemmelige numre indehaves af abonnenter, som også har kendte telefonnumre (for eksempel folk, der har hemmeligt telefonnummer i sommerhuset).

9. For at stikproven skal vare reprasentativ, hvad angår husstandsstorrelse, er man nodt til at forhore sig om husstandens storrelse og for eksempel af og til fravalge et-person husstande.

10. Kasper Vilstrup anforte i forbindelse med præsentationen af sit politiske indeks i Politiken (21/9 1994), at svarpct.en på 63 pct. var "bedre end normalt, nảr interviewperioden er på kun fire timer".

11. Der var flere kontaktpersoner, som med interesse omtalte eksperimenter, hor man beder tvivlere angive konkrete sandsynligheder for at stemme pă partier, man vakler imellem (for eksempel Hoek og Gendall, 1993).

12. Om vejning: se for eksempel Fuller (1974) og Poulsen (1981).

13. En metode til politisk vejning er omtalt i Hansen m.fl. (1992: 159).

14. Ved en statistisk korrekt anvendelse af chi-i-anden málet bør tilslutningen máles $i$ antal stemmer i stedet for pct.andele. I denne form bruges mălet til at teste en hypotese om, at den enkelte meningsmáling er en simpel tilfældig stikprove af det faktiske valgresultat. Problemet er imidlertid, at denne hypotese bedre kan testes, jo større stikprøven er. Fastholder man sảledes størrelsen af de enkelte procentafvigelser, fär man en større chi-i-anden værdi, jo større stikproven er. Da Gallup ikke ønskede, at stikprovens størrelse skulle påvirke málet, gik man blot ud fra, at alle meningsmålingerne byggede på 1000 personer. Dette viser, at man i realiteten var interesseret i et mål for procentafvigelserne. Det er endvidere lidt selvmodsigende, at Gallup foretrækker et mål, der lægger særlig vagt pá de små partiers afvigelse, når man i de månedlige meningsmålinger ikke oplyser tilslutning til de enkelte partier, som er mindre end to pct.

15. Dette er i høj grad til AIMs fordel, da meningsmålingen fra den $20 / 9$ var temmelig afvigende fra det faktiske valgresultat.

16. Her vil jeg tillade mig et hjertesuk. Nâr man interesserer sig for udviklingen i partiernes tilslutning, er det generende, at Gallup i forbindelse med sit månedlige indeks henviser partier med under to pct. tilslutning til gruppen "andre". Det gor dynamiske analyser unodvendigt komplicerede.

17. I en given stikprove betegnes andelen, som vaiger parti $n r i$, med $p_{i}$. Den tilsvarende andel i populationen, dvs. det faktiske valgresultat, betegnes med $\pi_{i}$. For alle $\mathrm{n}$ partier beregnes et indeks for absolut afvigelse fra det faktiske valgresultat ved

$$
\text { Abs.afv. }=\left(\Sigma\left|p_{i}-\pi_{i}\right|\right) / 2
$$

dvs. halvdelen af summen af forskellene mellem stikprovens og populationens andele uanset fortegn. Dette svarer til den andel af stikproven, der skulle flyttes mellem partierne for at give samme resultat som i populationen. Ved fuldstandig overensstemmelse mellem population og stikprøve antager indekset vardien 0 , mens værdien er 1 (100 pct.) ved fuldstændig uoverensstemmelse.

18. Den gennemsnitlige absolutte afvigelse $i$ en standard normalfordeling er beregnet til cirka 0.8 . I en simpel tilfældig stikprøve er differencen mellem $p_{i} \circ g \pi_{i}$ tilnærmet normalfordelt, og forventningen pà den absolutte afvigelse er

$$
\mathrm{E}\left(\left|\mathrm{p}_{\mathrm{i}}-\pi_{\mathrm{i}}\right|\right)=0.8 \operatorname{sqrt}\left[\pi_{\mathrm{i}}\left(1-\pi_{\mathrm{i}}\right) / \mathrm{N}\right]
$$

hvor $\mathrm{N}$ er stikprovens storrelse. Den forventede vardi pá indekset for abolut afvigelse (omtalt $\mathrm{i}$ forrige note) bliver derved

$$
\mathrm{E}(\text { Abs.afv. })=\mathrm{E}\left[\left(\sum\left|\mathrm{p}_{\mathrm{i}}-\pi_{\mathrm{i}}\right|\right) / 2\right]=0.4\left(\sum \mathrm{sqrt}\left[\pi_{\mathrm{i}}\left(1-\pi_{\mathrm{i}}\right)\right]\right) / \mathrm{sqrt}(\mathrm{N}) .
$$

I de tilfælde, hvor antal afgivne stemmer ikke er oplyst, er dette tal anslået til at være 85 pct. af antal gennemforte interviews. 


\section{Litteratur}

Avisarbogm, udgives atrligt af Pressehistorisk Selskab.

Babbie, Earl (1992). The Practice of Social Research, Sixth Edition, Belmont.: Wadsworth.

Barnett, Vic (1991). Sample Survey - Principle and Methods, London: Edward Arnold.

Blunch, Niels (1994). Indsamling af markedsdata, Herning: Systime.

Crespi, Irving (1988). Pre-election Polling: Sources of Accuracy and Error, New York: Sage.

Cristoffersen, Mogens Nygaard (1984). Brev, telefon, beseg, København: Socialforskningsinstituttet, studie 51.

Fuller, Carol H. (1974). "Weighting to Adjust for Survey Nonresponse", The Public Opinion Quarterly, vol. 27 , pp. 238-246.

Hansen, Flemming, Allan Grutt Hansen og Jens Rom Jensen (1992). Markedsanalyse: teknikker i praksis, Kobenhavn: Børsens Bøger.

Hoek, Janet A. og Philip J. Gendall (1993). "A New Method of Predicting Voting Behaviour", fournal of the Market Research Society, ảrg. 35, nr. 4, pp. 361-373.

Holmberg, Sören og Olof Petersson (1982). Inom Felmarginalen, Stockholm: Liber Forlag.

Jowell, Roger, Barry Hedges, Peter Lynn, Graham Farrant and Anthony Heath (1993). "The Polls - A Review. The 1992 British Election: The Failure of the Polls", Public Opinion Quarterly, vol. 57, pp. 238263.

Körmendi, Ester, Lisbeth Egmose og Johannes Noordhoek (1986). Datakvalitet ved telefoninterviev, Kobenhavn: Socialforskningsinstituttet, studie 52.

Larsen, Dan (1987). "Gallup Polling Accuracy in a Multi-Party Context: An Empirical Study of Twelve Danish Political Parties 1957-80", Scandinavian Political Studies, vol. 10, No. 4, pp. 357-368.

Mortensen, Peter S. (1994). Statistik for Økonomer - Reprcesentative undersegelser, Herning: Systime.

Poulsen, Carsten Stig (1981). "Opvejningsproblemer i stikproveundersøgelser", Erhvervsekonomisk Tidsskrift, nr. 3, pp. 153-158.

Schmidt, Marcus (1992). "Om spørgeskemaer og spørgsmálsformulering", i Per Darmer og Per V. Freytag (red), Erhorengabomomich tmderegaglegemerodib, Kehenhoun: Samfundelitteratur.

Schmidt, Marcus (1993). Direkte demokrati i Danmark - Om indforelse af et elektronisk andetkammer, København: Arnold Busk.

Thomsen, Søren Risbjerg (1993). "Valgvinden igen", Paper til arbejdsgruppen om lokalvalg, Nordisk Forbund for Statskundskab i Oslo, 1993, Arhus: Institut for Statskundskab. 